\title{
Four New Species of Dragon's Blood Croton (Euphorbiaceae) from South America
}

Author(s): Ana Carla Feio, Malu I. Ore-Rengifo, Paul E. Berry and Ricarda Riina

Source: Systematic Botany, 43(1):212-220.

Published By: The American Society of Plant Taxonomists

URL: http://www.bioone.org/doi/full/10.1600/036364418X697111

BioOne (www.bioone.org) is a nonprofit, online aggregation of core research in the biological, ecological, and environmental sciences. BioOne provides a sustainable online platform for over 170 journals and books published by nonprofit societies, associations, museums, institutions, and presses.

Your use of this PDF, the BioOne Web site, and all posted and associated content indicates your acceptance of BioOne's Terms of Use, available at www.bioone.org/page/terms_of_use.

Usage of BioOne content is strictly limited to personal, educational, and non-commercial use. Commercial inquiries or rights and permissions requests should be directed to the individual publisher as copyright holder. 


\title{
Four New Species of Dragon's Blood Croton (Euphorbiaceae) from South America
}

\author{
Ana Carla Feio, ${ }^{1}$ Malu I. Ore-Rengifo, ${ }^{2}$ Paul E. Berry, ${ }^{3}$ and Ricarda Riina ${ }^{4,5}$ \\ ${ }^{1}$ Programa de Capacitação Institucional, Museu Paraense Emílio Goeldi, Coordenação de Botânica. Av. Perimetral, \\ Terra Firme, CEP 66077-830, Belém, PA, Brazil; \\ anacarlafeio@gmail.com \\ ${ }^{2}$ Laboratorio de Sistemática y Diversidad Vegetal, Museo de Historia Natural, Universidad Nacional \\ Mayor de San Marcos, Av. Arenales 1256, Jesús María, Lima, Peru; \\ maluorergf@gmail.com \\ ${ }^{3}$ University of Michigan Herbarium, Department of Ecology and Evolutionary Biology, 3600 Varsity Drive, \\ Ann Arbor, Michigan 48108, U. S. A.; \\ peberry@umich.edu \\ ${ }^{4}$ Real Jardín Botánico, RJB-CSIC, Plaza de Murillo 2, 28014 Madrid, Spain; \\ rgriina@gmail.com \\ ${ }^{5}$ Author for correspondence (rgriina@gmail.com) \\ Communicating Editor: Luciano Paganucci Queiroz
}

\begin{abstract}
We describe and illustrate four new species of dragon's blood trees (Croton sect. Cyclostigma) from western South America. Three of the species, Croton beckii from Bolivia and Peru, C. camposii from Peru, and C. santamartensis from Colombia, grow in montane Andean forest, whereas $C$. tumbesinus occurs in dry forest of the Tumbes/Piura ecoregion of western Ecuador and Peru. The characters that place them in Croton sect. Cyclostigma include the arborescent habit, the presence of reddish to yellowish latex, an indument of stellate trichomes, conspicuous and persistent stipules, acropetiolar/basilaminar nectary glands, and terminal inflorescences with bisexual cymules at the base. These new species give additional support for the Andean region being the main center of diversity of this Neotropical Croton clade, as well as being a region whose biodiversity knowledge is still incomplete.
\end{abstract}

Keywords-Andes, Crotoneae, diversity, dry forest, montane forest, Neotropics, taxonomy, Tumbes/Piura ecoregion.

The dragon's blood Croton sect. Cyclostigma Griseb. consists of 41 known species distributed from Mexico to northern Argentina (Van Ee et al. 2011), with its main center of diversity in the Andes region (Riina 2006). The four species described below, and the recently published C. amentiformis Riina, increase the number of species in the section to 46 . Members of this group are trees that grow predominantly in moist forests, including riverine, lowland, and montane forests (Riina et al. 2009), with only two species, C. churutensis Riina \& Cornejo and C. charaguensis Standl., known so far from dry forest in Ecuador and Bolivia, respectively (Riina et al. 2007). Most Croton sect. Cyclostigma species are commonly known as "dragon's blood" due to their abundant reddish latex, which is used for medicinal purposes across their geographical range (Jones 2003).

The tropical Andes are a well known hotspot for biodiversity (Myers et al. 2000), however knowledge of their biodiversity seems far from complete, with many new species, and even genera, being described in recent years in different lineages of organisms (e.g. Kaczmarek et al. 2014; Michelangeli et al. 2014; Shimbori and Shaw 2014; Lagomarsino and SantamaríaAguilar 2016; Brito et al. 2017; Wurdack and Farfan-Rios 2017), including many new Croton species (Murillo 1999; Smith 2006; Riina and Berry 2010; Riina et al. 2007, 2014, 2015). This work represents one more contribution to this increasing list of taxonomic novelties for this genus in the Andes and adjacent areas, and also supports the claim about the importance of herbarium collections in the discovery of plant diversity (Bebber et al. 2010).

Three of the new species (C. beckii, C. camposii, and C. santamartensis) occur in Andean montane forest above $600 \mathrm{~m}$ elevation, whereas C. tumbesinus grows at lower elevations in dry forests of the Tumbes/Piura ecoregion, a biogeographic unit that covers coastal areas of southwestern Ecuador and northwestern Peru (Loaiza 2013). For each species we provide a full description, plates with images from herbarium specimens or from the field, recommendations regarding their conservation status, and comparisons with morphologically similar species among the dragon's blood Croton.

\section{MATERIALS AND MethodS}

Comparative morphological study of the new species was conducted using collections from the following herbaria: A, COL, DAV, E, F, GUAY, LPB, M, MA, MICH, MO, MOL, USM, and WIS. Protologues and type specimens of similar arborescent dragon's blood Croton from Andean montane forest and from the Tumbes/Piura dry forest ecoregion (www. worldwildlife.org/ecoregions/nt0232) were studied and compared with the new species. Terminology about trichomes and glandular structures follows Webster et al. (1996), Vitarelli et al. (2015), and Feio et al. (2016).

Information about habit, habitat, and distribution was taken from specimen labels and personal field observations. The distribution maps were created using QGIS 2.18.14 (Quantum GIS Development Team 2017). The online Geospatial Conservation Assessment Tool (GeoCAT) (Bachman et al. 2011, http://geocat.kew.org) was used to estimate extent of occurrence $(\mathrm{EOO})$ and area of occupancy (AOO) for species with more than two different localities. EOO and AOO were used in turn to evaluate species conservation status under the IUCN criteria (IUCN 2012).

\section{TAXONOMic TREATMENT}

Croton beckii Riina \& Feio, sp. nov. Type: Bolivia. Dpto. La Paz: Prov. Sud Yungas, Centro Lavi, above Irupana, 2300 m, 19 Aug 1996, S. G. Beck 22759 (holotype: LPB!, isotypes: MA!, MO!, WIS!).

This species differs from the morphologically closest species Croton pseudofragrans Croizat in having stipitate, stellate-porrect trichomes on the leaf abaxial side, inflorescences with flowers regularly distributed along the axis, and sessile pistillate flowers with bifid styles (vs. appressed-stellate trichomes on the leaf abaxial side, congested inflorescences, and pedicellate pistillate flowers with four-fid styles in C. pseudofragrans).

Monoecious trees, up to $15 \mathrm{~m}$ tall; young branches with a dense indumentum of stipitate stellate-porrect and fasciculate trichomes; latex reddish. Leaves alternate; stipules $2.8-5.2 \mathrm{~mm}$ long, linear-subulate, persistent, with dense indumentum of sessile stellate trichomes; petioles $0.8-2.7 \mathrm{~cm}$ long, with a dense indumentum of stipitate stellate-lepidote (15-30\% webbing) trichomes; nectary glands 2, acropetiolar, sessile to shortly stipitate, patelliform, incurved toward the abaxial side; blades 
10-12 $\times 4.5-5.2 \mathrm{~cm}$, ovate-lanceolate, base rounded to slightly truncate, apex acute, margin slightly denticulate and revolute, with minute ovoid colleters on the teeth, abaxial surface with stipitate stellate-porrect trichomes, adaxial surface with fasciculate to stipitate-fasciculate trichomes, venation brochidodromous, secondary veins in 10-12 pairs, prominent on the abaxial side. Inflorescences $8-10 \mathrm{~cm}$ long, axillary and terminal, erect, proximal cymules with 2-3 pistillate flowers, distal cymules with single staminate flowers regularly spaced along most of the axis; axis with a dense indumentum of stellate appressed trichomes; bracts triangular, $0.5-1 \times 0.3 \mathrm{~mm}$. Staminate flowers with pedicels 5-7 mm long; sepals 3-4 $\times 2-2.5 \mathrm{~mm}$, ovate with acuminate apex, valvate, adaxial surface glabrous with tiny simple trichomes at the base, abaxial surface with a dense indumentum of stellate trichomes, margin pilose; petals $2.5 \times 0.8-1 \mathrm{~mm}$, oblong-lanceolate, with acute apex, abaxial side pilose, adaxial side with scattered trichomes, margin pilose; receptacle densely pilose; stamens $27-34$, filaments $2-3 \mathrm{~mm}$ long, pilose, anthers $0.5-0.8 \times 0.3-0.5 \mathrm{~mm}$. Pistillate flowers sessile to subsessile; sepals $3.8-4 \times 1.1-1.5 \mathrm{~mm}$, partially fused at the base, abaxial surface with dense indumentum of stipitate to sessile stellate-lepidote trichomes, adaxial surface glabrous; ovary 3.8-4 × 2.0-2.2 mm, styles 3, bifid, with stellate trichomes at the base. Capsules and seeds unknown. Figures 1, 2.

Additional Specimens Examined-Bolivia.-LA PAZ: Prov. Sud Yungas, de Chulumani 7 km al NE, 2000 m, 24 Sep 1994, S. G. Beck 22223 (LPB)

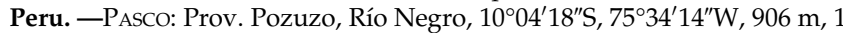
May 2015, G. Gerlach s.n. (M, MA, photo vouchers).

Distribution and Habitat-Montane forest on the eastern side of the Andes. The species is known from two disjunct areas in Peru and Bolivia and it has been collected between 900-2300 m elevation (Fig. 1).

Phenology-This species has been collected with flowers in May and August.

Conservation Status-We suggest that if an evaluation were performed, $C$. beckii be categorized as data deficient (DD) because it is only known from two localities and three collections. The species is likely to be present in the intervening areas along the eastern slopes of the Andes of Peru and Bolivia.

Etymology-The specific epithet honors Prof. Stephan G. Beck from the National Herbarium of Bolivia (LPB).

Notes-Croton beckii is supported as a member of Croton sect. Cyclostigma based on DNA sequence data (Riina, unpubl. data) in addition to morphological evidence. This species could be unique in the section because of the lack of proximal bisexual cymules, however the plant material available does not allow us to be conclusive about this character. In overall appearance, $C$. beckii bears some resemblance to $C$. pseudofragrans in Croton sect. Cleodora (Klotzsch) Baill. (Caruzo et al. 2013) and with C. condorensis Riina \& Cerón, a species of unknown sectional affinity (Riina et al. 2014). The three species occupy similar montane forest habitats along the eastern side of the Andes, have axillary inflorescences, and similar leaf shape and size. However, C. beckii can be distinguished from C. pseudofragrans by several characters, namely stipitate stellate-porrect trichomes on the leaf abaxial side, inflorescences with flowers regularly distributed along the axis, and sessile pistillate flowers with bifid styles (vs. appressedstellate trichomes on the leaf abaxial side, congested inflorescences, and pedicellate pistillate flowers with four-fid styles in $C$. pseudofragrans). Croton beckii differs from $C$. condorensis by having acropetiolar nectary glands and sessile pistillate flowers with narrow sepals (vs. basilaminar nectary glands and pedicellate pistillate flowers with large accrescent sepals in C. condorensis).
Croton camposii Riina \& Ore-Rengifo, sp. nov. TyPe: Peru. San Martin: Rioja to Pedro Ruiz, border with Amazonas, 1800 m, 4 Dec 2003, T. D. Pennington, R. T. Pennington $\mathcal{E}$ A. Daza 17644 (holotype: E!, isotype: MOL).

This species is morphologically most similar to C. perspeciosus Croizat, but it differs from it in having subulate stipules, longer pedicellate pistillate flowers, and 34-38 stamens (vs. foliaceous and ciliate stipules, sessile to subsessile pistillate flowers, and ca. 45 stamens in C. perspeciosus).

Monoecious trees, ca. $8 \mathrm{~m}$ tall; young branches with dense indumentum of fasciculate and rosulate trichomes, sometimes with a porrect ray; latex clear to reddish. Leaves alternate; stipules 5-8 mm long, subulate, densely covered by fasciculate or rosulate porrect trichomes, colleters minute along the margins and tip; petioles 4-15 cm long, with dense indumentum of fasciculate trichomes; blades 13-30 × 11-25 cm, ovate, base cordate, apex acute to acumminate, margins entire with minute ovoid colleters towards the base; nectary glands $6-8$, basilaminar, patelliform, stipitate or sessile, mostly on the abaxial side, venation brochidodromous, abaxial surface densely covered with rosulate trichomes, adaxial surface with scattered fasciculate and rosulate trichomes, primary and secondary veins raised and densely covered with rosulate trichomes on both surfaces. Inflorescences 15-30 cm long, terminal, erect, proximal cymules bisexual, distal cymules unisexual (staminate), staminate flowers regularly spaced along the axis; axis costate, with a dense indumentum of fasciculate and rosulate trichomes; bracts ca. 0.6-1.2 $\times$ 0.3-1.0 $\mathrm{mm}$, triangular. Staminate flowers with pedicels $0.7-1.1 \mathrm{~cm}$ long; sepals $1.5-2 \times 2-3 \mathrm{~mm}$, valvate, ovate, adaxial and abaxial surfaces with fasciculate and rosulate trichomes; petals 1-1.5 mm long, ovate with acuminate apex, valvate, adaxial and abaxial surface glabrous with abundant pilose trichomes along the margin; receptacle densely pilose; stamens 34-38, filaments 3-5 mm long, pilose at the base, anthers $0.5-0.8 \times$ $0.3-0.5 \mathrm{~mm}$. Pistillate flowers with pedicels $1.1-1.9 \mathrm{~cm}$ long, densely covered by fasciculate and rosulate trichomes; sepals 4.3-7.5 × 2.9-3.8 mm, cuneate, valvate, adaxial surface with scattered rosulate trichomes, abaxial surface with dense rosulate trichomes, sometimes with a porrect ray, apex acute; ovary densely covered with fasciculate and rosulate trichomes, styles 3 , twice bifid (12 tips), with a few fasciculate trichomes at the base. Capsules 6-8 $\times$ 8-9 mm, globose, trilobed, densely covered with rosulate-porrect trichomes, columella $6.0-6.5 \mathrm{~mm}$ long; seeds 5-5.5 $\times 3.7-4.0 \mathrm{~mm}$, ellipsoid, rugose, light brown; caruncle $0.7-0.8 \times 1.4-1.5 \mathrm{~mm}$, trapezoidal. Figures 1, 3 .

Additional Specimens Examined-Peru.-AMAZONAS: Prov. Rodríguez de Mendoza, Sector Vista Alegre, home at roadside, $05^{\circ} 40^{\prime} 12^{\prime \prime} \mathrm{S}$, $77^{\circ} 45^{\prime} 21^{\prime \prime} \mathrm{W}, 1820 \mathrm{~m}, 19$ May 2004, R. Riina \& J. Campos 1463 (MA, MICH,

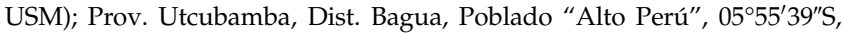
78 $27^{\prime} 15^{\prime \prime} \mathrm{W}, 2171 \mathrm{~m}, 02$ Jun 2017, L. Santa 3552 (MA).

Distribution and Habitat-Dwarf montane forest in Amazonas Province near the border with San Martin Province in northern Peru, between 1800-2200 m elevation (Fig. 1).

Etymology-The specific epithet honors the Peruvian plant collector José Campos, who collected one of the paratypes of this species with the last author.

Phenology-This species has been collected with flowers and fruits from May to December.

Conservation Status-As with many Croton species, C. camposii grows in secondary successional environments, so forest perturbations likely promote its persistence. The extent of occurrence (EOO) is more than $20,000 \mathrm{~km}^{2}$, and the area of occupancy (AOO) is greater than $2000 \mathrm{~km}^{2}$. Therefore we suggest that if 


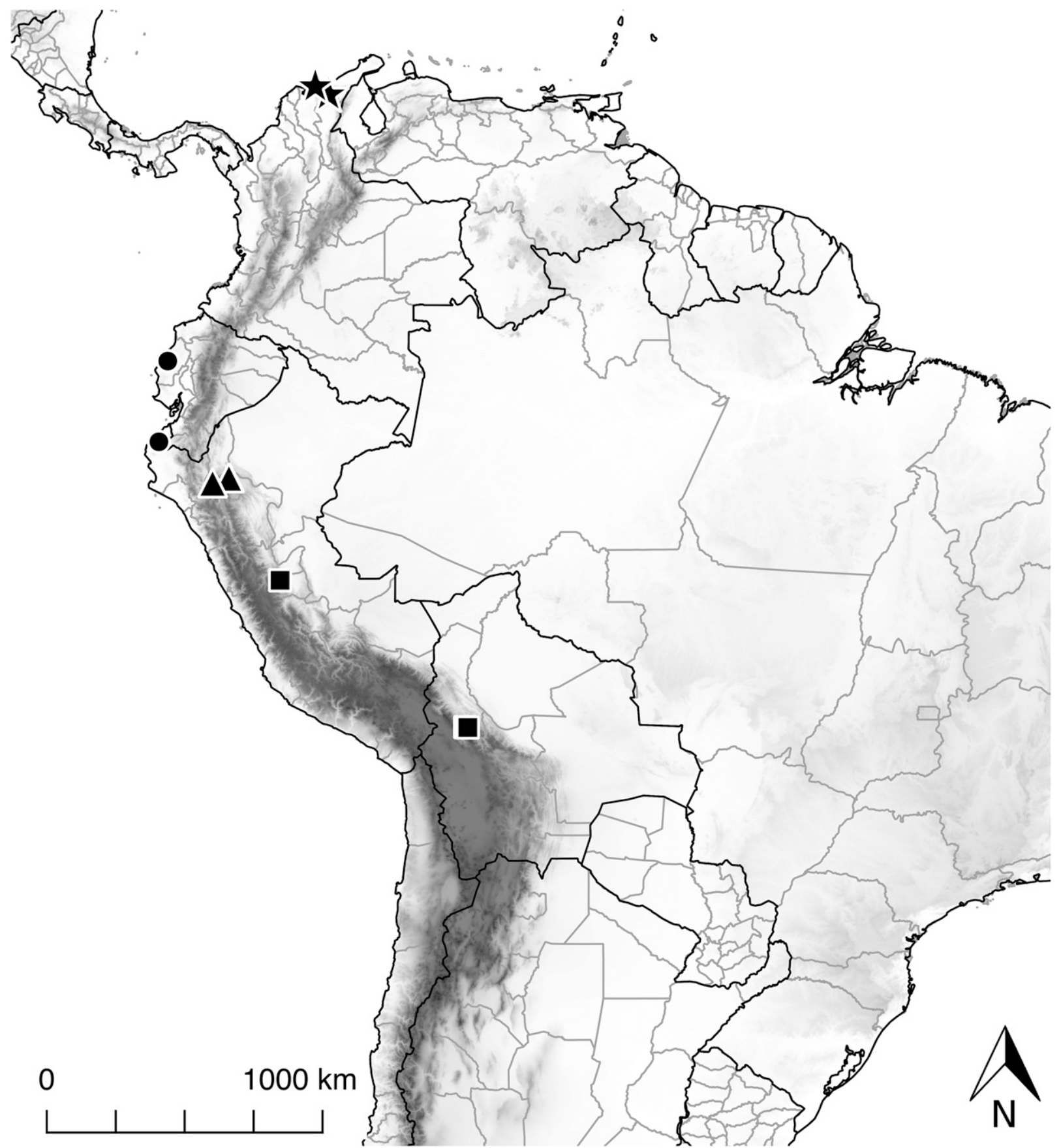

FIG. 1. Distribution map showing known localities of the four new species. Croton santamartensis (stars), C. tumbesinus (circles), C. camposii (triangles), and C. beckii (squares).

an evaluation were performed the species be considered as least concern (LC).

Notes-Croton camposii is most similar to C. perspeciosus in overall aspect, but it can be easily distinguished from the latter in having subulate stipules, fasciculate trichomes, pedicellate pistillate flowers with cuneate sepals, and 34-38 stamens. Croton perspeciosus has large, foliose stipules with highly dissected or ciliate margins, stellate porrect trichomes with the central ray much longer than the others, and sessile to subsessile pistillate flowers with ovate-lanceolate sepals and ca. 45 stamens on average.

Croton santamartensis Riina \& P.E.Berry, sp. nov. TYPE: Colombia. Magdalena: Municipio de Santa Marta, from
Cerro Quemado to Cincinnati, 2600-2800 m, 19 Apr 1959, R. Romero-Castañeda 7781 (holotype: COL!).

Croton santamartensis differs from its most similar species, $C$. purdiei Müll.Arg., in its shorter and entire stipules, 4-12 acropetiolar nectary glands, and wide stigmatic surface (vs. longer and branched stipules, 2 acropetiolar nectary glands, and narrow stigmatic surface).

Monoecious trees, 4-9 $\mathrm{m}$ tall; young branches with a dense indumentum of rosulate and stellate appressed trichomes; latex reddish. Leaves alternate; stipules 3.3-4.9 $\mathrm{mm}$ long, linear, with scattered appressed rosulate trichomes, and minute ovoid colleters along the margins; petioles $2-10 \mathrm{~cm}$ long, with a sparse indumentum of stellate and rosulate 


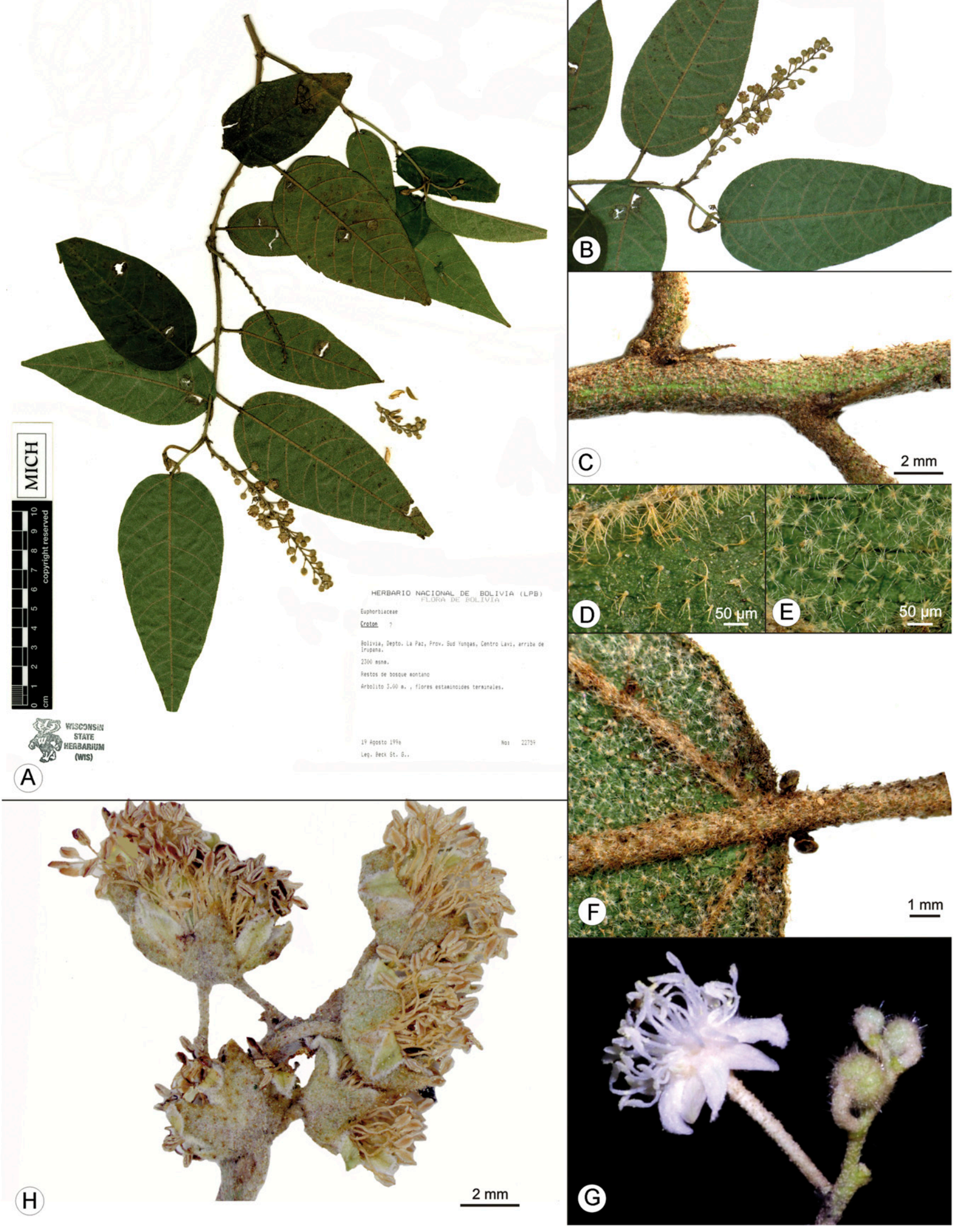

Fig. 2. Croton beckii. A. Image of the holotype showing a flowering branch. B. Detail of inflorescence. C. Apical part of a branch showing the stipules. D. Trichomes on the adaxial side of the leaf. E. Trichomes on the abaxial side of the leaf. F. Acropetiolar nectary glands incurved towards the abaxial side. G. Detail of staminate flower and staminate flower buds. H. Part of inflorescence showing staminate flower. Photo G courtesy of G. Gerlach (Gerlach s.n.). A-F, H: Beck 22759. 


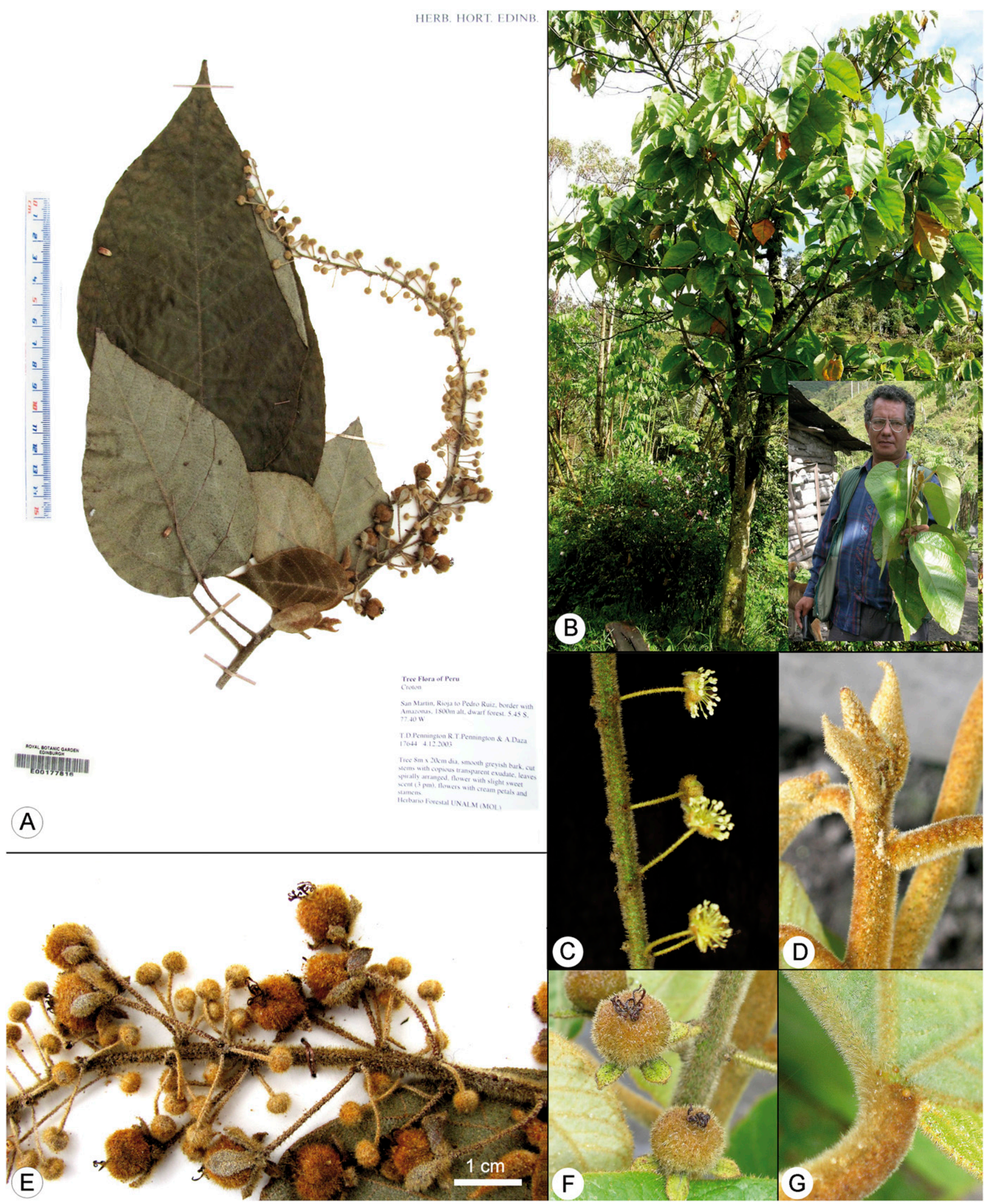

FIG. 3. Croton camposii. A. Image of the isotype (MOL) showing a flowering branch. B. Adult individual in its natural habitat with J. Campos, after whom this species is named, holding a specimen (inset). C. Detail of staminate flowers. D. Apical part of a branch showing the stipules, young leaf and stem apex. E. Part of inflorescence showing cymules with pistillate flowers and buds of staminate flowers. F. Young fruits. G. Basilaminar nectary glands mostly on the abaxial side. A, E: Pennington et al. 17644; B-D, F-G: Riina \& Campos 1463. Photos: R. Riina. 
appressed trichomes; nectary glands $4-12$, acropetiolar, stipitate, attached to the petiole on the adaxial side, with scattered stellate and rosulate appressed trichomes on the stipe, nectary surface convex to patelliform; blades $4-25 \times 2-15 \mathrm{~cm}$, ovatelanceolate, base rounded (young leaves) to cordate (mature leaves), apex acute-acuminate, margins entire with minute ovoid colleters, adaxial surface with sparse indumentum of stellate and rosulate appressed trichomes, abaxial surface with similar but denser indumentum; venation brochidodromous, secondary veins 8-10 pairs, brochidodromous, with secondary veins raised on the abaxial surface. Inflorescences $8-21.5 \mathrm{~cm}$ long, terminal, erect, proximal and distal cymules usually bisexual, regularly spaced from base to apex, with 3-7 pistillate flowers at the base of the inflorescence axis; axis costate, with a dense indumentum of stellate and rosulate trichomes; bracts triangular, 2-2.5 $\times$ $1 \mathrm{~mm}$. Staminate flowers with pedicels $3.5-8.1 \mathrm{~mm}$ long; sepals $2-3.3 \times 1-2.0 \mathrm{~mm}$, valvate, triangular with an acute apex, abaxial surface densely covered with rosulate trichomes, adaxial surface with a dense indumentum of stellateporrect rosulate trichomes; petals 2-3.5 $\times 0.7-0.9 \mathrm{~mm}$, oblong-cuneate, with simple and trichomes on abaxial surface, margins entire; receptacle densely pilose; stamens 35-44, filaments 2-3 mm long, pilose, anthers $0.6-1 \times$ $0.3-0.5 \mathrm{~mm}$. Pistillate flowers with pedicels $1.5-2 \mathrm{~mm}$ long, with stellate-porrect and rosulate trichomes; sepals 3-6 $\times$ 2-3.5 mm, valvate, oblong-ovate, apex acute, abaxial side covered with stellate and rosulate appressed trichomes, adaxial side with scattered simple trichomes, margins pilose; petals highly reduced, linear; ovary densely covered with stellate and rosulate appressed trichomes, styles 3, bifid, flattened and widened in their apical portion, stellate and rosulate appressed trichomes on the lower part of the style branches. Capsules 6-8 $\times$ 5-7 mm, subglobose, densely covered with stellate and rosulate appressed trichomes; columella 6-9 mm long; seeds unknown. Figures 1, 4.

Additional Specimens Examined —Colombia. —CÉSAR: Sierra Nevada de Santa Marta, southeastern slopes. Trail between Sogrome and Sacarecungue along Rio Donachui, $5500 \mathrm{ft}(1670 \mathrm{~m}), 9$ May 1975, T. Plowman \& W. Davis 3653 (COL). - Magdalena: San Lorenzo, San Lorenzo (Sierra Nevada), 2100 m, 10 Jul 1969, N. de López 242 (COL); ca. 2200 m, 26 Feb 1927, A. Schultze 779 (A); cuchilla de San Lorenzo a orillas de la carretera que conduce a Cerro Kennedy, 2100-2475 m, 7 Dec 1977, C. Barbosa et al. 313 (COL); Cuchilla de San Lorenzo, alrededores del Centro Forestal, 18 Jun 1969, S. Diaz P. 117 (COL); same locality, same date, S. Diaz P. 142 (COL); Sierra Nevada de Santa Marta, $74^{\circ} 07^{\prime} 23^{\prime \prime} \mathrm{W}, 11^{\circ} 08^{\prime} 53^{\prime \prime}, 615 \mathrm{~m}$, 22 Nov 2008, R. Cortez 2584 (COL); 2200 m, 09 Aug 1984, E. Carbonó 1042 (COL); Cerro Kennedy, near top of higher peak in N massif of Sierra Nevada de Santa Marta, $74^{\circ} 01^{\prime} \mathrm{W}, 1^{\circ} 05^{\prime} \mathrm{N}, 2580-2600 \mathrm{~m}, 24$ Aug 1986, A. Gentry \& H. Cuadros 55553 (MO); Cerro Kennedy, near top of higher peak in N massif of Sierra Nevada de Santa Marta, 2550-2570 m, Transect 3, 24 Aug 1986, A. Gentry \& H. Cuadros 55568A (F, MO); Cerro Kennedy, Transect 7, $74^{\circ} 01^{\prime} \mathrm{W}, 11^{\circ} 05^{\prime} \mathrm{N}, 2620 \mathrm{~m}, 14 \mathrm{Jan} 1989$, A. Gentry $\mathcal{E}$ H. Cuadros 64648 (MO); carretera arriba de Minca, $74^{\circ} 04^{\prime} 47^{\prime \prime} \mathrm{W}, 11^{\circ} 07^{\prime} 05^{\prime \prime} \mathrm{N}, 1200-1550 \mathrm{~m}, 4$ Nov 2008, G. Galeano 7595 (COL); Municipio de Santa Marta, Cerro Quemado, 2600-2800 m, 15 Apr 1959, R. Romero-Castañeda 7695 (COL); entre Cerro Quemado y Cerro San Lorenzo, 2600-2800 m, 16 Apr 1959, R. RomeroCastañeda 7725 (COL); Entre la Estación Forestal del INDERENA y Cerro Quemado, 8 Aug 1971, R. Romero-Castañeda \& S. Llinás 11260 (COL).

Etymology-The specific epithet refers to the occurrence location of this species in the Sierra Nevada de Santa Marta.

Distribution and Habitat-Croton santamartensis occurs in montane forest at mid and high elevations, 650-2800 m, and it is only known from few localities in the Sierra de Santa Marta Massif in northern Colombia (Fig. 1).

Phenology_Flowering from January to August.
Conservation Status-We suggest that if an evaluation were performed, $C$. santamartensis should be categorized as Vulnerable (VU B1ab[iii]) because it has been collected in fewer than ten locations, and its geographic range is smaller than $20,000 \mathrm{~km}^{2}$. The specimens examined are from two disjunct areas outside Sierra Nevada de Santa Marta National Natural Park. Northwest of the national park is the La MicaCuchilla San Lorenzo-Cerro Kennedy area in Magdalena Department, where most of the collections are from, and the second locality is SSE of the park (between Sogrome and Sacarecungue) in César Departament. It is likely that C. santamartensis occurs inside the national park in montane forest areas similar to the ones where it has been collected.

Notes-The new species is most similar to C. purdiei Müll. Arg., but $C$. santamartensis differs from that species in its shorter and entire stipules (3.3-4.9 mm long), greater number of petiolar nectary glands (4-12), widened stigmatic surface (vs. stipules 11.6-20.5 mm and usually branched, paired petiolar nectary glands, and stigmatic surface not widened in C. purdiei).

Croton tumbesinus Riina, sp. nov. TyPE: PerU. Tumbes: Tumbes, Pampas de Hospital El Caucho, quebrada Faical between El Caucho and Campo Verde, 370 m, 21 Jan 1989, C. Diaz, T. Pennington \& C. Reynel 3199 (holotype: MO!, isotypes: F!, MICH!, MOL!).

Croton tumbesinus differs from its morphologically and geographically closest species, C. churutensis, in having filiform and entire stipules, unlobed leaves, and bifid styles (vs. dissected stipules, usually 2-3-lobed leaves, and tetrafid styles in C. churutensis).

Monoecious trees, 2.5-5 m tall; young branches with a sparse to dense indumentum of stellate-porrect trichomes; latex unknown. Leaves alternate; stipules 1-2.7 mm long, linear, filiform with a glandular tip (colleter), glabrous or with sparse stellate trichomes; petioles $2-6 \mathrm{~cm}$ long, with a more or less dense indumentum of stellate appressed trichomes; blades 5-15 × 3-9 cm, ovate to broadly ovate, base slightly cordate to rounded, apex acute to mucronate, margins entire, with tiny ovoid colleters and sparse simple trichomes, adaxial surface with indumentum sparse to almost glabrous, trichomes stellate-multiradiate, sessile, sometimes porrect, abaxial surface with dense to sparse indumentum, trichomes stellatemultiradiate, sessile, sometimes porrect; nectary glands 2-4, basilaminar, patelliform, stipitate; venation 3-5-plinerved, secondary veins $3-5$, tertiary veins scalariform, primary and secondary veins raised on the abaxial leaf surface. Inflorescences 20-30 cm long, terminal, delicate, nodding, proximal cymules bisexual, distal ones unisexual (staminate), regularly spaced along the axis; axis costate, with a sparse indumentum of stellate-multiradiate trichomes; bracts linear-lanceolate, ca. $0.8-1.0 \times 0.1-0.3 \mathrm{~mm}$, usually glandular at the base and apex. Staminate flowers with pedicels $1.4-5 \mathrm{~mm}$ long with scattered stellate trichomes; sepals $1.2-1.3 \times 0.5-1 \mathrm{~mm}$, valvate to slightly imbricate, ovate-lanceolate, adaxial surface glabrous, abaxial surface glabrous, sometimes with sparse stellate trichomes at the base, apex lanate; petals $1.2-1.3 \times 0.2-0.8 \mathrm{~mm}$, narrowly elliptical, cuneate, glabrous on both surfaces, margins and apex lanate, receptacle densely pilose; stamens 16, filaments $1.5-2.5 \mathrm{~mm}$ long, hairy at the base, anthers $0.6-$ $0.7 \times 0.4-0.5 \mathrm{~mm}$. Pistillate flowers with pedicels $3-7.3 \mathrm{~mm}$ long, with sparse stellate-multiradiate trichomes; sepals 2.1-2.3 × 0.9-1.4 mm, valvate to slightly imbricate, broadly ovate, adaxial surface glabrous, abaxial surface almost 

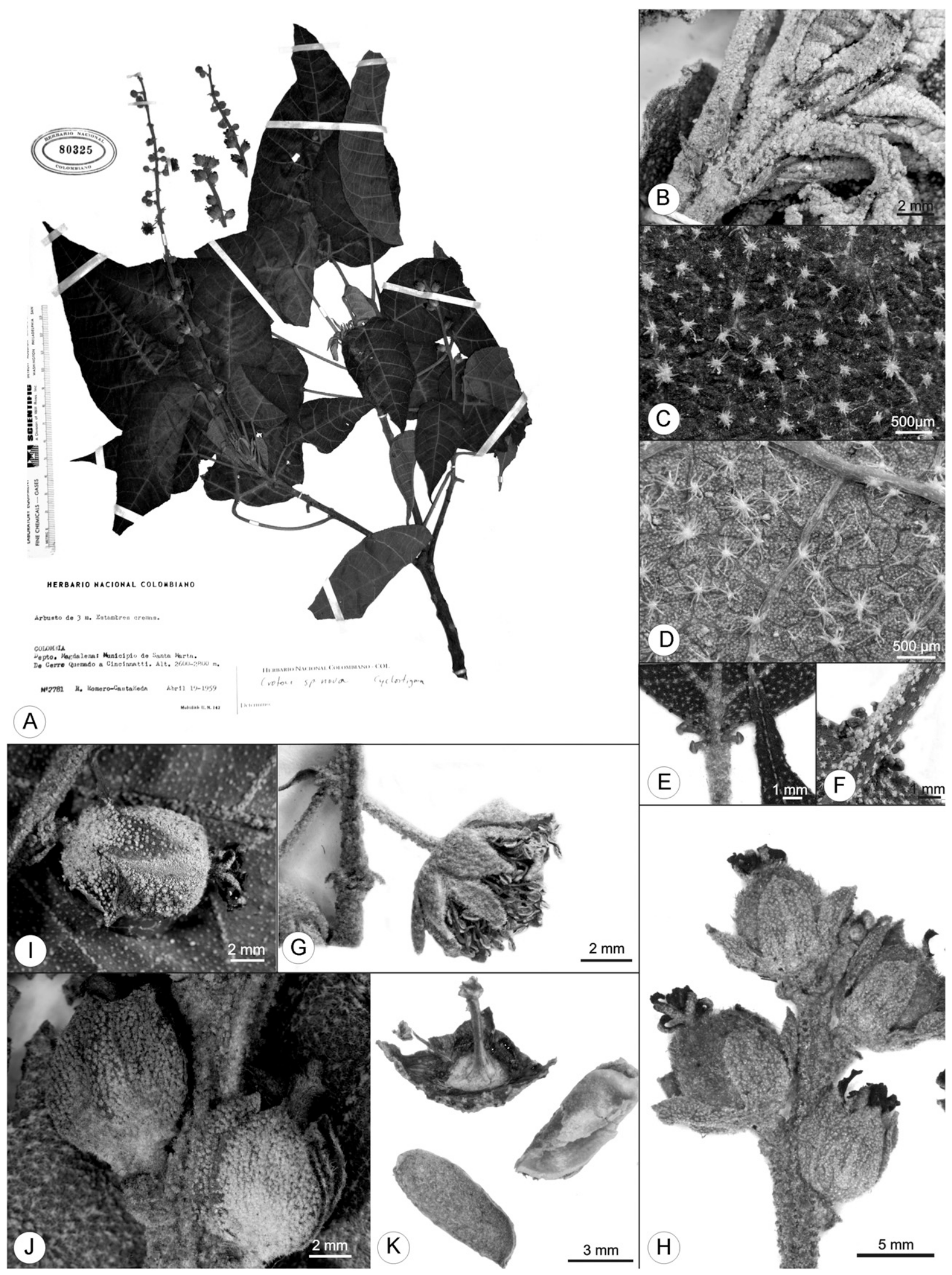

FIG. 4. Croton santamartensis. A. Image of the holotype showing a flowering branch. B. Apical part of a branch showing the stipules and young leaf. C. Trichomes on the adaxial side of the leaf. D. Trichomes on the abaxial side of the leaf. E. Acropetiolar nectary glands seen from the adaxial side. F. Acropetiolar nectary glands seen from the abaxial side. G. Detail of staminate flower. H. Part of inflorescence with pistillate flowers in different stages of maturity. I. Immature fruits J. Young pistillate flowers. K. Remains of two mericarps; persistent calyx and columella. A, H: Romero-Castañeda 7781; B, K: Romero-Castañeda 7695; C-D, F: Díaz et al. 117; E, G: Romero-Castañeda \& Llinás 11260; I: Gentry \& Cuadros 55568A; J: Romero-Castañeda 7725. 

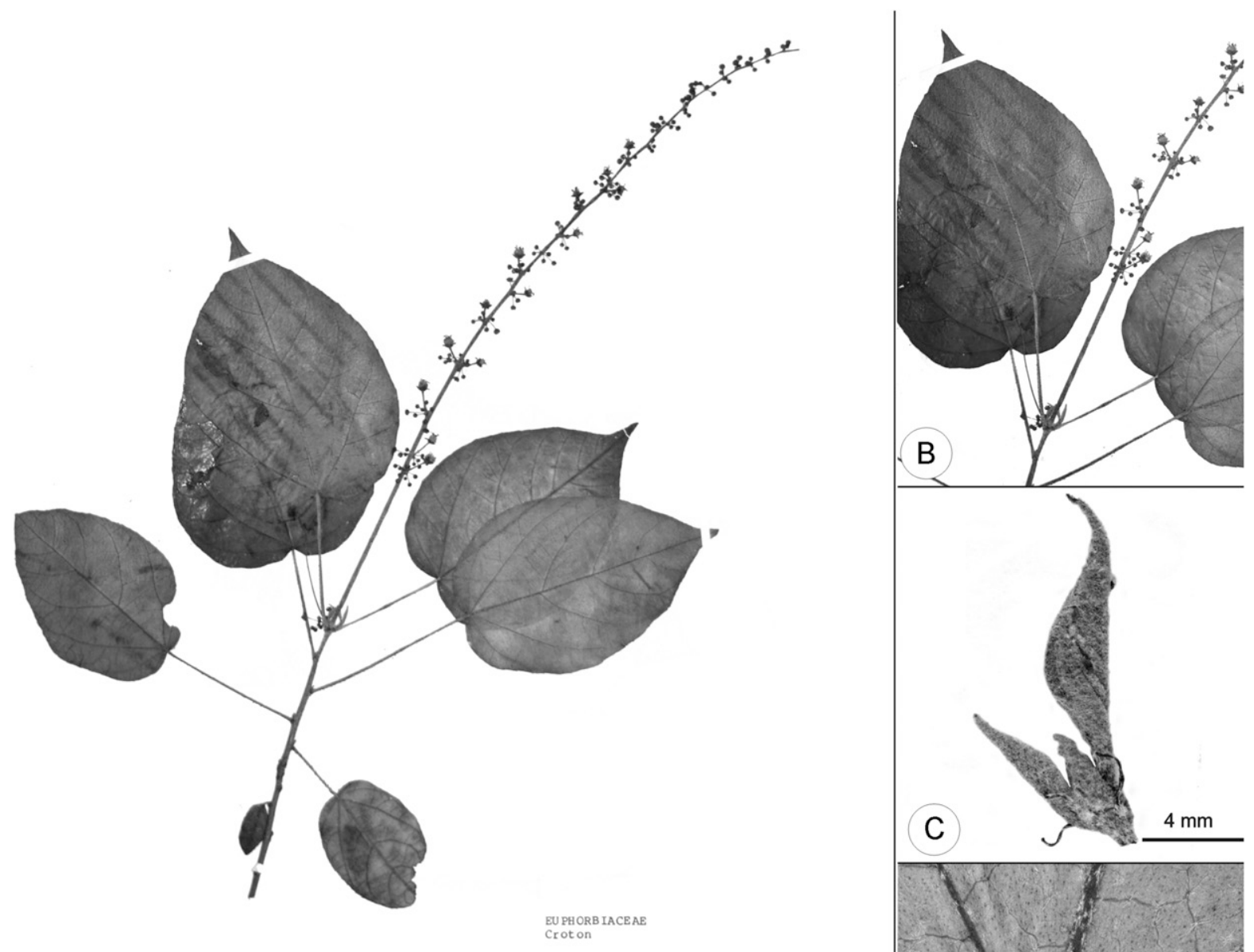

EUPHORB IACEAE
Crot ON

TUMBES : Tumbes Province Pampas de Hospital E1 Caucho, quebrada
"Paical "entre "El Caucho" y Campo verde No 2109350

Arbusto, $2.50 \mathrm{~m}$. F1ores cremoso verdosas OF NATURAL HISTORY

A

C. Diaz, T. Pennington o C. Reyne1 1989
MISSOURI BOTAN ICAL GARDEN HERBARIUM (MO)
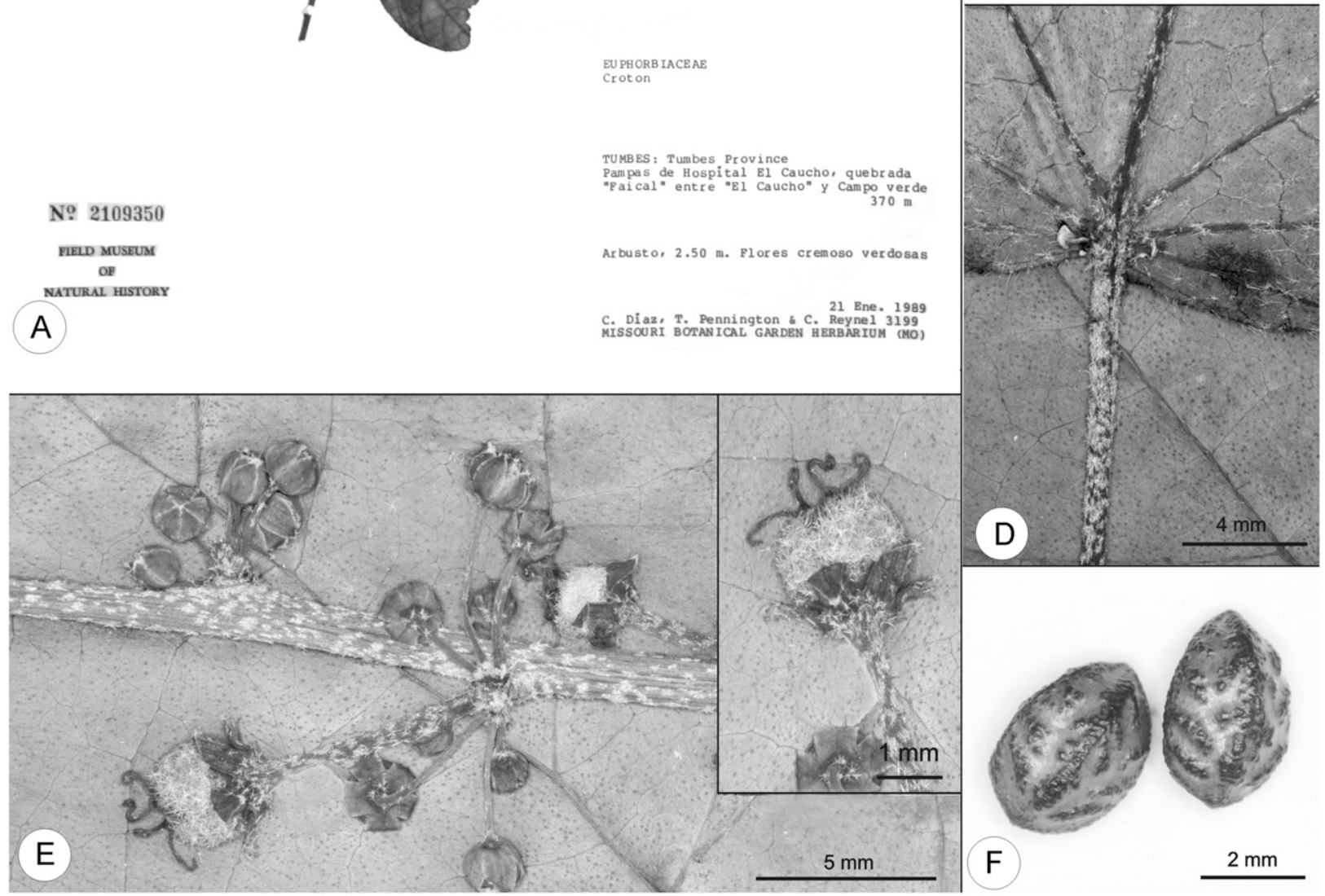

Fig. 5. Croton tumbesinus. A. Image of the holotype showing a flowering branch. B. Apical part of a branch showing the stipules and part of inflorescence. C. Apical part of a branch showing the stipules and young leaf. D. Trichomes and basilaminar nectary glands on the abaxial side; adaxial surface of another leaf on the lower part of the photo. E. Part of inflorescence with pistillate flowers and staminate flower buds; inset with pistillate flower. F. Seeds, ventral side. A-B, D-F: Diaz et al. 3199; C: Cornejo \& Bonifaz 1755. 
glabrous, sparse stellate multiradiate trichomes at the base, apex lanate; petals absent or reduced to a sessile gland; ovary densely covered with stellate-mutiradiate trichomes, styles 3 , bifid, glabrous or with a few stellate trichomes at the base. Capsules 5-6 $\times 5-6 \mathrm{~mm}$, globose, trilobed; columella 3.0-4.0 mm long; seeds 3.9-4.0 × 2.6-2.9 mm, ovoid, light brown with dark brown muri, rugose; caruncle trapezoidal, ca. $0.4 \times 0.8 \mathrm{~mm}$. Figures 1, 5 .

Additional Specimens Examined-Ecuador. -MANABt: Bahia de Caráquez, tropical forest very dry to dry, in front of Isla Corazón, $00^{\circ} 40^{\prime} \mathrm{S}$, $80^{\circ} 22^{\prime} \mathrm{W}, 190$ m, 18 Feb 1994, X. Cornejo \& C. Bonifaz 1755 (DAV, GUAY, WIS). Peru. - Tumbes: Zarumilla, Región below El Caucho, dry tropical forest, 350-450 m, 18 Feb 1976, T. Plowman 5487 (DAV).

Etymology-The specific epithet refers to the Tumbes-Piura dry forest ecoregion located between Ecuador and Peru, where the species appears to be endemic.

Distribution and Habitat-This species is only known from dry coastal forests of Tumbes Department in Peru and Manabí Province in Ecuador, where it grows at 190-450 m elevation (Fig. 1). The known populations appear to be disjunct, but they occupy the same type of dry coastal forest vegetation.

Phenology-This species has been collected with flowers in January and February.

Conservation Status-We suggest that if an evaluation were performed, C. tumbesinus should be categorized as Data Deficient (DD) because it is only known from two localities and three collections. The species is likely to be present in the intervening areas along the northwestern coastal of Peru and western of Ecuador.

Notes-Croton tumbesinus shares the same type of habitat, dry forest, with C. churutensis, another dragon's blood tree that is only known from Ecuador. It is possible the two species cooccur in some areas of the Tumbes/Piura dry forest ecoregion, but so far there are no records of them growing in sympatry. The two species differ in several morphological features, but the most obvious ones are leaves, stipules, and styles. Croton churutensis has lobed leaves, stipules ovate-lanceolate, and conspicuously laciniate, and multifid styles (12 to 14 tips), where in C. tumbesinus the leaves are unlobed, stipules are filiform and entire, and styles are bifid (6 tips).

AcKNowledgments. We are grateful to the staff of the abovementioned herbaria for allowing us to examine specimens from their collections. Christine Niezgoda (F) and Alfredo F. Fuentes (LPB) kindly sent us specimen images. We are grateful to Otavio M. L. da Silva for assistance with the QGIS software. ACF was supported by a CNPq research grant and the Programa de Capacitação Institucional (MPEG/ MCTIC). MIOR was supported by a mobilization scholarship from the National Fund for Scientific Development, Technological and Technological Innovation-FONDECYT, CONCYTEC (Lima, Peru), for a two-month internship at the RJB-CSIC in 2017. RR received support from the Synthesys Programme (GBTAF-2834). Three reviewers and the editors provided valuable comments and suggestions to improve earlier versions of this manuscript.

\section{Literature Cited}

Bachman, S., J. Moat, A. W. Hill, J. de Torre, and B. Scott. 2011. Supporting red list threat assessments with GeoCAT: Geospatial conservation assessment tool. ZooKeys 150: 117.

Bebber, D. P., M. A. Carine, J. R. I. Wood, A. H. Wortley, D. J. Harris, G. T. Prance, G. Davidse, J. Paige, T. D. Pennington, N. K. B. Robson, and R. W. Scotland. 2010. Herbaria are a major frontier for species discovery. Proceedings of the National Academy of Sciences USA 107: 22169-22171.

Brito, J. M., N. Tinoco, D. Chávez, P. Moreno-Cárdenas, D. Batallas, and R. Ojala-Barbour. 2017. New species of arboreal rat of the genus
Rhipidomys (Cricetidae, Sigmodontinae) from Sangay National Park, Ecuador. Neotropical Biodiversity 3: 65-79.

Caruzo, M. B., I. Cordeiro, P. E. Berry, and R. Riina. 2013. A new species of Croton section Cleodora (Euphorbiaceae s.s.) from Minas Gerais, Brazil. Phytotaxa 3: 27-33.

Feio, A. C., R. Riina, and R. M. S. A. Meira. 2016. Secretory structures in leaves and flowers of two dragon's blood Croton (Euphorbiaceae): New evidence and interpretations. International Journal of Plant Sciences 177: 511-522.

IUCN. 2012. IUCN red list categories and criteria version 3.1. Ed. 2. Gland, Switzerland and Cambridge, UK: IUCN.

Jones, K. 2003. Review of sangre de drago (Croton lechleri) - A South American tree sap in the treatment of diarrhea, inflammation, insect bites, viral infections, and wounds: traditional uses to clinical research. Journal of Alternative and Complementary Medicine (New York, N.Y.) 9: 877-896.

Kaczmarek, Ł., J. Cytan, K. Zawierucha, D. Diduszko, and L. Michalczyk. 2014. Tardigrades from Peru (South America), with descriptions of three new species of Parachela. Zootaxa 3790: 357-379.

Lagomarsino, L. P. and D. Santamaría-Aguilar. 2016. Two new species of Siphocampylus (Campanulaceae, Lobelioideae) from the Central Andes. PhytoKeys 58: 105-117.

Loaiza, C. R. 2013. The Tumbesian center of endemism: Biogeography, diversity and conservation. Biogeografía 6: 4-10.

Michelangeli, F. A., C. U. Ulloa, and K. Sosa. 2014. Quipuanthus, a new genus of Melastomataceae from the foothills of the Andes in Ecuador and Peru. Systematic Botany 39: 533-540.

Murillo, J. 1999. Composición y distribución del género Croton (Euphorbiaceae) en Colombia, con cuatro especies nuevas. Caldasia 21: 141-166.

Myers, N., R. A. Mittermaier, C. G. Mittermaier, G. A. B. da Fonseca, and J. Kent. 2000. Biodiversity hotspots for conservation priorities. Nature 403: 853-858.

Quantum GIS Development Team. 2017. Quantum GIS Geographic Information System. Open Source Geospatial Foundation Project. http://www.qgis.org/ (accessed 27 Oct 2017).

Riina, R. 2006. Molecular systematics of the neotropical dragon's blood trees Croton sect. Cyclostigma (Euphorbiaceae). Ph.D. thesis. Madison, Wisconsin: University of Wisconsin.

Riina, R. and P. E. Berry. 2010. Two new South American species of Croton (Euphorbiaceae) and their phylogenetic affinities. Anales del Jardin Botanico de Madrid 67: 23-27.

Riina, R., P. E. Berry, and X. Cornejo. 2007. A new species of "sangre de drago" (Croton section Cyclostigma, Euphorbiaceae) from coastal Ecuador. Brittonia 59: 97-101.

Riina, R., P. E. Berry, and B. W. van Ee. 2009. Molecular phylogenetics of the dragon's blood Croton section Cyclostigma (Euphorbiaceae): A polyphyletic assemblage unraveled. Systematic Botany 34: 360-374.

Riina, R., M. A. Vigo, and C. E. Cerón. 2014. Croton condorensis: An enigmatic new species of Euphorbiaceae from southern Ecuador. Phytotaxa 164: 154-158.

Riina, R., N. Cumbicus, A. C. Feio, C. E. Cerón, R. M. S. A. Meira, and P. E. Berry. 2015. A new species of dragon's blood Croton (Euphorbiaceae) from South America with singular inflorescences. Webbia 70: 187-192.

Shimbori, E. M. and S. R. Shaw. 2014. Twenty-four new species of Aleiodes Wesmael from the eastern Andes of Ecuador with associated biological information (Hymenoptera, Braconidae, Rogadinae). ZooKeys 405: 1-81.

Smith, B. A. 2006. A new species of Croton (Euphorbiaceae) from Ecuador. Novon 16: 272-275.

Van Ee, B. W., R. Riina, and P. E. Berry. 2011. A revised infrageneric classification and molecular phylogeny of New World Croton (Euphorbiaceae). Taxon 60: 791-823.

Vitarelli, N. C., R. Riina, M. B. R. Caruzo, I. Cordeiro, J. Fuertes-Aguilar, and R. M. S. A. Meira. 2015. Foliar secretory structures in Crotoneae (Euphorbiaceae): Diversity, anatomy, and evolutionary significance. American Journal of Botany 12: 833-847.

Webster, G. L., M. J. Del-Arco-Aguilar, and B. A. Smith. 1996. Systematic distribution of foliar trichome types in Croton (Euphorbiaceae). Botanical Journal of the Linnean Society 121: 41-57.

Wurdack, K. J. and W. Farfan-Rios. 2017. Incadendron: a new genus of Euphorbiaceae tribe Hippomaneae from the sub-Andean cordilleras of Ecuador and Peru. PhytoKeys 85: 69-86. 